\title{
LIFE CYCLE ASSESSMENT FOR THE PRODUCTION OF PALM BIODIESEL
}

\section{CHEE LIANG YUNG ${ }^{*, \star *} ;$ VIJAYA SUBRAMANIAM* and SUMIANI YUSOFF ${ }^{\ddagger}$}

\begin{abstract}
A gate-to-gate life cycle assessment (LCA) for the production of palm biodiesel was performed. The LCA study was conducted using SimaPro software version 8.5, and the impact assessment was performed according to ReCiPe 2016 methodology. A three-year (2015-2017) inventory data was obtained from five commercial palm biodiesel producers in Malaysia. Methanol, acids and sodium methoxide (catalyst) were identified as three major contributors to the environmental impacts. Impact assessment showed that replacement of fossilbased methanol with biomethanol produced from biogas is the most preferred option, saving up to 63\% fossil resources and 22\% reduction in global warming impact. Allocation based on economic value was found more suitable compared to mass or energy content. This is because both palm biodiesel and crude glycerol differ in terms of economic value and being used in different applications.
\end{abstract}

Keywords: LCA, palm biodiesel, transesterification.

Received: 18 March 2020; Accepted: 2 June 2020; Published online: 7 October 2020.

\section{INTRODUCTION}

Biodiesel is an important industry for Malaysia. The commercial production of palm biodiesel in Malaysia began in 2006 with the setting up of three commercial biodiesel plants, registering a total production of $54981 \mathrm{t}$ (Harrison, 2018). With 15 plants in commercial production in 2018, the annual production volume of palm biodiesel had then exceeded one million tonnes. Out of the total biodiesel produced, $515000 \mathrm{t}$ were sold, generating an export earnings of RM 1.43 billion, while $429000 \mathrm{t}$ were utilised for the biodiesel programme implemented locally (MPOB, 2019; Unnithan, 2019).

Refined, bleached and deodourised (RBD) palm oil is the typical feedstock for biodiesel production in Malaysia. During biodiesel manufacturing,

\footnotetext{
* Malaysian Palm Oil Board,

6 Persiaran Institusi, Bandar Baru Bangi,

43000 Kajang, Selangor, Malaysia.

E-mail: clyung@mpob.gov.my

** Department of Civil Engineering,

Faculty of Engineering, Universiti Malaya,

50603 Kuala Lumpur, Malaysia.

‡ Institute of Ocean and Earth Sciences,

Universiti Malaya, 50603 Kuala Lumpur, Malaysia.
}

RBD palm oil is reacted with methanol in the presence of an alkaline catalyst to produce palm methyl ester (PME) or palm biodiesel (Figure 1). The transesterification reaction is carried out at $60^{\circ} \mathrm{C}$ under an atmospheric pressure (Van Gerpen and Knothe, 2010). Commercially, the reaction is typically performed in two or three reactors with a continuous flow system. Glycerol, the by-product of transesterification, is separated from the methyl ester phase in settling tanks by gravity or using a centrifuge to expedite the phase separation. Upon removal of the glycerol phase, acid is used for neutralisation of the residual catalyst in the methyl ester phase and at the same time to split any soap that is formed between the alkaline catalyst and free fatty acids. Soap reacts with acid to form water-soluble salts which will be removed in the water washing process. Excess methanol is removed, recovered and reused in the transesterification reaction. Any remaining catalyst, soaps, salts, methanol and free glycerol are further removed from methyl ester during water washing. Lastly, water is removed by a vacuum dryer. PME with water content below 500 $\mathrm{mg} \mathrm{kg}^{-1}$ is stored at a bulk storage facility and ready to be used as biodiesel. The glycerol produced is also subjected to a series of purification, i.e. acidulation, neutralisation and methanol recovery to produce 
crude glycerol with a purity of $80 \%-85 \%$. Crude glycerol is typically sold to glycerol refiners for further purification before it is used for downstream applications.

The environmental evaluation of biodiesel, particularly palm biodiesel using life cycle assessment (LCA) approach has been conducted by various parties globally for the past decades. These LCA studies were mostly cradle-to-gate or cradle-tograve type which emphasised mainly on greenhouse gas (GHG) emissions (Yee et al., 2009; De Souza et al., 2010; Choo et al., 2011; Mohd Nor Azman et al., 2011; Silalertruksa and Gheewala, 2012; Norfaradila et al., 2014; Kittithammavong et al., 2014; Siregar et al., 2015; Maharjan et al., 2017). It was reported that the main contributors to the environmental impacts were the production and utilisation of chemical fertilisers in oil palm plantations and biogas (mainly methane) emission from palm oil mill effluent (POME). Hence, these studies suggested various rectification steps within these sectors to minimise the environmental impacts. Thus far, there were very little information reported on the evaluation of activities in biodiesel production. Furthermore, some of the studies were conducted solely based on secondary data, with several assumptions that did not reflect the actual activities of the industry. For example, most of the biodiesel produced in Malaysia was from RBD palm oil (Unnithan, 2019) and not crude palm oil
(CPO), as assumed in several studies (Yee et al., 2009; Silalertruksa and Gheewala, 2012; Siregar et al., 2015). Some of the researchers also assumed that both palm oil and palm kernel oil were mixed and used for the production of biodiesel (Arvidsson et al., 2012). Hence, there was an obviously wrong assumption and some data gaps due to the missing inventory data on palm oil refining, which is an important stage of the palm oil and palm biodiesel industry in the country.

The current study was conducted with a specific aim to evaluate the environmental performance of the production of palm biodiesel on various impact categories which focus specifically on the activities in the biodiesel plant. It was also aimed to provide an up-to-date information on the palm biodiesel production in Malaysia, after the last published study conducted a decade ago (Puah et al., 2010). Some of the parameters might have changed, as the numbers of biodiesel producers, and the total production volume have increased tremendously, based on the improvements of the various technology providers. In general, the LCA study was conducted in accordance to ISO standards, namely ISO 14040 Environmental management Life cycle assessment - Principles and framework and ISO 14044 Environmental management - Life cycle assessment - Requirements and guidelines (ISO, 2006a, b).

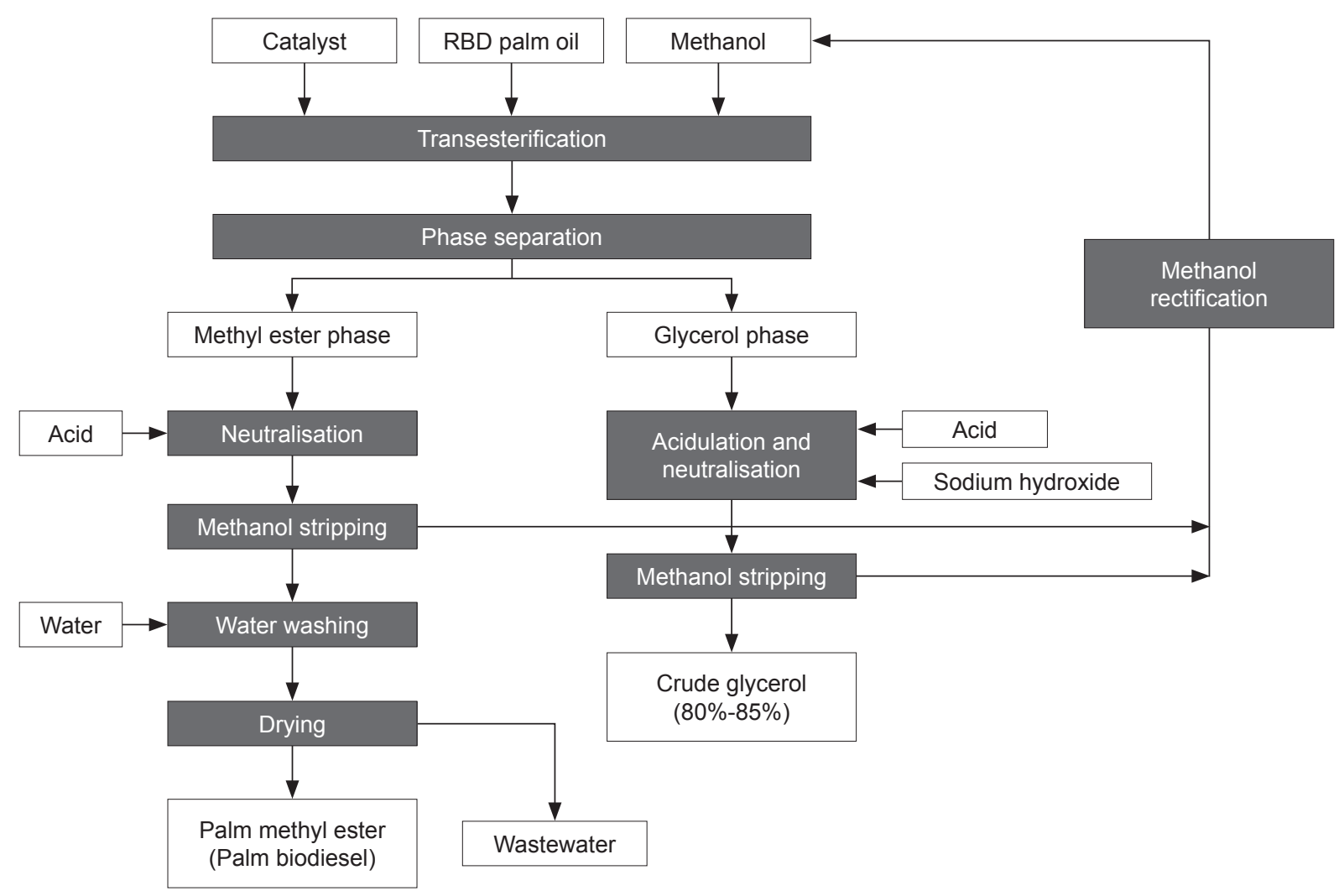

Figure 1. Process flow chart for the production of palm biodiesel. 


\section{MATERIALS AND METHODS}

\section{Goal and Scope Definition}

The scope of the study focused on gate-to-gate production of palm biodiesel in commercial plants located in Malaysia. Transesterification using alkaline catalyst was the chemical process involved, and the main feedstock was RBD palm oil.

The goals of the study were to provide an upto-date life cycle inventory data for the production of palm biodiesel in Malaysia, to perform a life cycle impact assessment (LCIA), and finally to evaluate the proposed options for environmental improvement within the scope of the study and the system boundary.

\section{Functional Unit}

The main product in a biodiesel plant is biodiesel that meets the Malaysian Standard Specification for PME, MS2008:2014 (Department of Standards Malaysia, 2014). Crude glycerol with a purity of $80 \%-85 \%$ is a by-product of biodiesel production. Both biodiesel and crude glycerol are commercially traded in tonne (mass) basis. Thus, the appropriate functional unit is the production of $1 \mathrm{t}$ of products, i.e. palm biodiesel and crude glycerol.

\section{System Boundary}

The inventory data obtained were based on a gate-to-gate basis, starting from transportation of feedstock, i.e. RBD palm oil from palm oil refineries to biodiesel plants, transesterification of RBD palm oil to produce PME, purification of methyl ester and glycerol to produce palm biodiesel according to the standard specification and crude glycerol.

\section{Inventory Data Collection}

The inventory data for the production of palm biodiesel were gathered from five active biodiesel producers in Malaysia, three in Peninsular Malaysia, one each in Sabah and Sarawak. A three-year (2015-2017) factory operation data were collected for this purpose through dissemination of survey questionnaires. Data clarification and verification were carried out through e-mail and telephone communications. Besides site-specific foreground data, background data were obtained from the databases available in the SimaPro software, i.e. Ecoinvent 3.4, Agri-footprint and USLCI databases (PRé Consultants, 2018). The background process for the production of chemicals used in the transesterification process, i.e. methanol, sodium methoxide $30 \%$ (catalyst), sodium hydroxide (neutralising agent), acids, electricity supply from the Malaysian power grid, fossil fuels supply for steam production and water supply were referred to Ecoinvent 3.4 database. The emissions for transportation of RBD palm oil from refineries to biodiesel plants and the combustion of fossil fuels for steam production were referred to Agri-footprint and USLCI databases, respectively.

\section{Co-products Allocation}

Both palm biodiesel and crude glycerol are commercially traded according to their economic value in open market. Hence, allocation based on economic value was used in the study. The annual trading prices for palm biodiesel and crude glycerol were obtained from Thomson Reuters commodity platform to derive the 10-year average prices of palm biodiesel and crude glycerol. These prices were used to generate the allocation ratio of 96.8:3.2 for palm biodiesel and crude glycerol. Allocation methods based on mass and energy value were also evaluated and discussed in the sensitivity analysis of the study.

\section{LCIA}

Impact assessment is a process to link the inventory data to respective environmental impacts. In this study, the impact assessment was conducted using SimaPro software version 8.5 (PRéConsultants, 2018). ReCiPe 2016 (Hierarchist) methodology was used for the impact assessment at midpoint level (Huijbregts et al., 2017). Environmental impacts on global warming, ionising radiation, ozone formation, terrestrial acidification and fossil resource scarcity were analysed and discussed.

\section{Exclusion}

The data for capital goods such as building structures of biodiesel plants, equipment and machinery used were excluded in the study because of difficulty in getting reliable data. Besides, these data have no significant environmental impacts as reported in the previous studies (Puah et al., 2010; Malca and Freire, 2011; Schneider and Finkbeiner, 2013). Treatment of wastewater was also excluded in the current study for similar reasons.

\section{RESULTS AND DISCUSSION}

\section{Inventory Analysis}

The total volume of palm biodiesel produced by the five producers was $802112 \mathrm{t}$ or $42.3 \%$ of the total biodiesel production in Malaysia from 2015-2017. The weighted average data for the production of $1 \mathrm{t}$ palm biodiesel are presented in Table 1 . The inventory data are presented as tonne 
of palm biodiesel produced, differing from the data reported by Puah et al. (2010) which focussed on the production and use of $1 \mathrm{MJ}$ palm biodiesel in diesel vehicles or engines. In the previous study, the biodiesel production data were only obtained from two biodiesel producers. However, the major feed materials for biodiesel production in Malaysia were similar, i.e. RBD palm oil and methanol. In general, the predominant feedstock for biodiesel production in Malaysia is still RBD palm oil (94.5\%) after more than a decade of commercial production. This is mainly due to its availability, as most of the $\mathrm{CPO}$ produced here is refined into RBD palm oil before being used for downstream edible and non-edible applications (Yung et al., 2020). Furthermore, RBD palm oil is easily handled in biodiesel plants compared to CPO, as no pre-treatment or additional acid esterification is required for the former to get rid of its free fatty acids due to its low acidity. Other cheaper feedstocks in use are RBD palm stearin $(3.8 \%)$ and palm fatty acid distillate (PFAD) $(1.7 \%)$, producing small volume of biodiesel which were catered for the export market. Methanol is commonly used simply because it is the least expensive alcohol available globally.

On average, approximately $1 \mathrm{t}$ of palm oil is required to react with $109 \mathrm{~kg}$ of methanol to produce $1 \mathrm{t}$ of palm biodiesel and $127 \mathrm{~kg}$ of crude glycerol (Table 1). The catalyst used by all five producers for transesterification process in this study was sodium methoxide with $30 \%$ concentration, which differed from the sodium hydroxide as reported by Puah et al. (2010). Sodium methoxide is widely available in the commercial market at the present day and its global market value was estimated at around USD 0.3 billion (MarketWatch, 2019). It is more convenient for biodiesel producers in handling and storing sodium methoxide compared to sodium hydroxide. Furthermore, the on-site preparation of sodium hydroxide in liquid solution will potentially produce water which might adversely affect the transesterification reaction if the water is not removed from the solution (Van Gerpen and Knothe, 2010). Nevertheless, sodium hydroxide solution is used instead as a neutralising agent at the glycerol polishing stage. Acids in the form of hydrochloric acid, citric acid and acetic acid are commonly used by the producers to facilitate separation of crude glycerol from methyl ester phase. Similar to palm oil refineries, fossil fuels are used for steam production in the boiler house. Natural gas is used by producers in Peninsular Malaysia and Sarawak while petroleum diesel is the only option for the producer in Sabah. The average water consumption

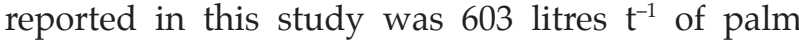
biodiesel produced, $66 \%$ higher than the value reported by Puah et al. (2010). In general, biodiesel plants are located at industrial areas near palm oil refineries. In fact, some of the biodiesel plants are part of the downstream activities next to the refinery complexes. Hence, the distance between the supply of RBD palm oil to biodiesel plant is very minimal. From the inventory data collected, less than $10 \mathrm{tkm}$ was reported for transportation of feedstock to biodiesel plants.

TABLE 1. INVENTORY OF BIODIESEL PRODUCTION (per tonne of palm biodiesel produced)

\begin{tabular}{lcc}
\hline Item & Unit & Amount \\
\hline Input & & \\
Refined, bleached and deodourised (RBD) palm oil & $\mathrm{t}$ & 0.9406 \\
RBD palm stearin & $\mathrm{t}$ & 0.0380 \\
Palm fatty acid distillate (PFAD) & $\mathrm{t}$ & 0.0166 \\
Total feed material & $\mathrm{t}$ & 0.9952 \\
Methanol & $\mathrm{kg}$ & 108.8932 \\
Sodium methoxide 30\% (catalyst) & $\mathrm{kg}$ & 9.4371 \\
Hydrochloric acid & $\mathrm{kg}$ & 9.5788 \\
Citric acid & $\mathrm{kg}$ & 0.8725 \\
Acetic acid & $\mathrm{kg}$ & 0.1396 \\
Sodium hydroxide (neutralising agent) & $\mathrm{kg}$ & 0.7853 \\
Electricity & $\mathrm{kWhr}$ & 37.1409 \\
Boiler fuel & & \\
Natural gas & $\mathrm{m}$ & 6.0749 \\
Diesel & $\mathrm{kg}$ & 0.0081 \\
Fuel oil & $\mathrm{kg}$ & 0.1348 \\
Water & $\mathrm{litre}$ & 603.1306 \\
Average distance from palm oil refineries to biodiesel plant & $\mathrm{km}$ & 9.2864 \\
Transport of feed oil to biodiesel plant & $\mathrm{tkm}$ & 9.2418 \\
Output & & \\
Palm biodiesel & $\mathrm{t}$ & 1.0000 \\
Crude glycerol & $\mathrm{kg}$ & 127.4327 \\
\hline
\end{tabular}

Note: Weighted average data calculated from five palm biodiesel producers for year 2015-2017. 


\section{LCIA}

The characterised LCIA for the production of palm biodiesel at midpoint level is shown in Figure 2. For all impact categories, the top three significant contributors were methanol, acids and the catalyst. This was followed by the production of fossil fuels and its combustion in the boiler house for steam production. The use of sodium hydroxide as a neutralising agent, water, transportation and electricity from power grid barely played any significant role, $<5 \%$ to all the impact categories except for water scarcity. Approximately $30 \%$ of the impact on water scarcity was caused by the amount of water consumed in the biodiesel plant.

Methanol has significant impact to all the 18 midpoint impact categories, in particular, to the fossil and mineral resources scarcity, ozone formation (both effects on human health and terrestrial ecosystems), global warming, human non-carcinogenic toxicity, marine and freshwater ecotoxicity and stratospheric ozone depletion. More than $50 \%$ of the impact in these categories was due to methanol, followed by acids with substantial impact on marine eutrophication and land use. The use of sodium methoxide as the catalyst was significant in contributing to ionising radiation, freshwater eutrophication, terrestrial ecotoxicity and human carcinogen toxicity. Combustion of fossil fuels for steam production was an important contributor to terrestrial acidification, fine particulate matter formation and global warming. Water required for steam generation, cooling and biodiesel purification (water washing) only impacted the water consumption impact category.

Methanol is one of the most common chemicals supplied and shipped in the world with a total production which exceeded 95 billion litres every year (Hobson and Marquez, 2018). It is commercially produced mainly via syngas conversion using natural gas as feedstock.

Methanol was the single major contributor to the total GHG emitted, $77.8 \mathrm{~kg} \mathrm{CO}_{2}$ eq $^{-1}$ of palm biodiesel produced or $60 \%$ of the overall emissions (Figure 3). Replacement of fossil-based methanol with bioethanol or biomethanol is suggested to reduce the impact on global warming (Sampattagul et al., 2011; Noorazah et al., 2017). However, no detailed analysis is attainable thus far. Commercial production of biomethanol has gained recent attention as seen with the construction of several commercial biomethanol plants in Europe and North America (Hobson and Marquez, 2018).

Replacement of fossil-based methanol with biomethanol was evaluated in this study. Three scenarios were simulated, namely (1) biomethanol produced from biomass in Switzerland (Ecoinvent 3.4 database) and shipped to Malaysia, (2) biomethanol produced in Malaysia, modified from
(1) with Malaysian utilities and (3) biomethanol produced from biogas by replacing natural gas with bio-compressed natural gas (bio-CNG) produced from POME. For scenario 1, although production of biomethanol from biomass could significantly lower the global warming effect (Figure 3), the long distance required to transport biomethanol to Malaysia has offset most of the GHG savings earned. Overall, the total GHG emitted was recorded at $112.5 \mathrm{~kg} \mathrm{CO}_{2}$ eq t $\mathrm{t}^{-1}$ of palm biodiesel produced or equivalent to a saving of $13.2 \%$ compared to fossil-based methanol (Figure 3). No significant change was observed for scenario 2, mainly due to higher carbon emissions utilities in Malaysia compared to those in Switzerland. For scenario 3 , the substitution of fossil-based methanol with biomethanol deriving from POME contributed to the highest GHG emissions reduction with a saving of $28.9 \mathrm{~kg} \mathrm{CO}$ eq for every tonne of palm biodiesel produced (Figure 3). This, in fact is indicative of bio-CNG as an environmental-friendly chemical which does not contribute to any environmental burden since it is derived from a waste material in palm oil mills.

On the other hand, it was observed that the impact on ionising radiation was 5.7 times higher if fossil-based methanol was replaced by biomethanol produced in Switzerland (Figure 4). This was mainly attributed to the use of nuclearbased electricity for the production of syngas from biomass and subsequently biomethanol production. A simulated biomethanol production using local utilities as for scenario 2 significantly lowered the ionising radiation impact. No significant difference was observed for scenario 3 compared to fossilbased methanol.

The impact of ozone formation on human health and terrestrial ecosystems was again dominated by methanol $(61.8 \%)$, catalyst $(14.2 \%)$ and acids $(14.2 \%)$, as shown in Figure 5. This impact correlated strongly with transportation mode of methanol. The long distance transportation of biomethanol produced in Switzerland to Malaysia raised the total impact on ozone formation to 2.4 times higher than that using fossil-based methanol. However, there was no significant change for scenarios 2 and 3 as the distance involved was assumed to be relatively shorter. The same was observed for terrestrial acidification impact category with 1.9 times higher score mainly due to long distance transportation (Figure 6).

For fossil resource scarcity impact category, significant savings of fossil resources, i.e. natural gas, was observed for all scenarios if fossil-based methanol was replaced by biomethanol (Figure 7). Savings of $59.9 \mathrm{~kg}$ oil eq to $65.3 \mathrm{~kg}$ oil eq (more than 50\% savings) per tonne of palm biodiesel produced was recorded for all three biomethanol scenarios. 
Based on the LCIA analysis, changing of feed materials from fossil-based to natural resources may not always resolve the associated environmental impacts. It happened that only a few impact categories were affected.

\section{Sensitivity Analyses - Allocation of Co-products}

Evaluation of different allocation methods, i.e. allocation based on economic value, energy content and mass value to that of no allocation with all the environmental burden assigned to palm biodiesel only was conducted (Figure 8). Both palm biodiesel and crude glycerol are the main product and coproduct from biodiesel plants. They are traded at different market prices. Based on the inventory data collected, $88.7 \%$ of the total products, measured by mass, was palm biodiesel, and the remaining $11.3 \%$ was crude glycerol. Allocation ratio of 96.8:3.2 was derived from the average 10-year prices of palm biodiesel and crude glycerol, whereas allocation ratio of 94.4:5.6 was based on energy content assuming that the calorific values of palm biodiesel and crude glycerol are $40.0 \mathrm{MJ} \mathrm{kg}^{-1}$ and $18.5 \mathrm{MJ} \mathrm{kg}^{-1}$, respectively.
Figure 8 shows that the environmental impacts attributed to palm biodiesel was reduced by $11 \%$ based on smaller mass value assigned to the crude glycerol portion. This allocation is very straight forward and can be easily performed based on systematic record of the production figures of biodiesel and crude glycerol by all producers. However, the appropriateness of such allocation ratio is always questioned as similar environmental burden will be obtained for the production of $1 \mathrm{t}$ of palm biodiesel and $1 \mathrm{t}$ of crude glycerol although it is known that these two products are different in terms of economic value and energy content. It might be more appropriate to assign the environmental burden based on their economic value and energy content. As such, $3.2 \%$ and $5.6 \%$ of the overall environmental burden were allocated to $127 \mathrm{~kg}$ of crude glycerol produced. Based on the economic value, the environmental burden for the production of $1 \mathrm{t}$ of palm biodiesel has become 3.9 times higher than that for $1 \mathrm{t}$ of crude glycerol. If crude glycerol were to be used as an energy source, e.g. as a fuel for boiler or industrial burner, its environmental burden will be slightly less than half that of $1 \mathrm{t}$ of palm biodiesel produced.

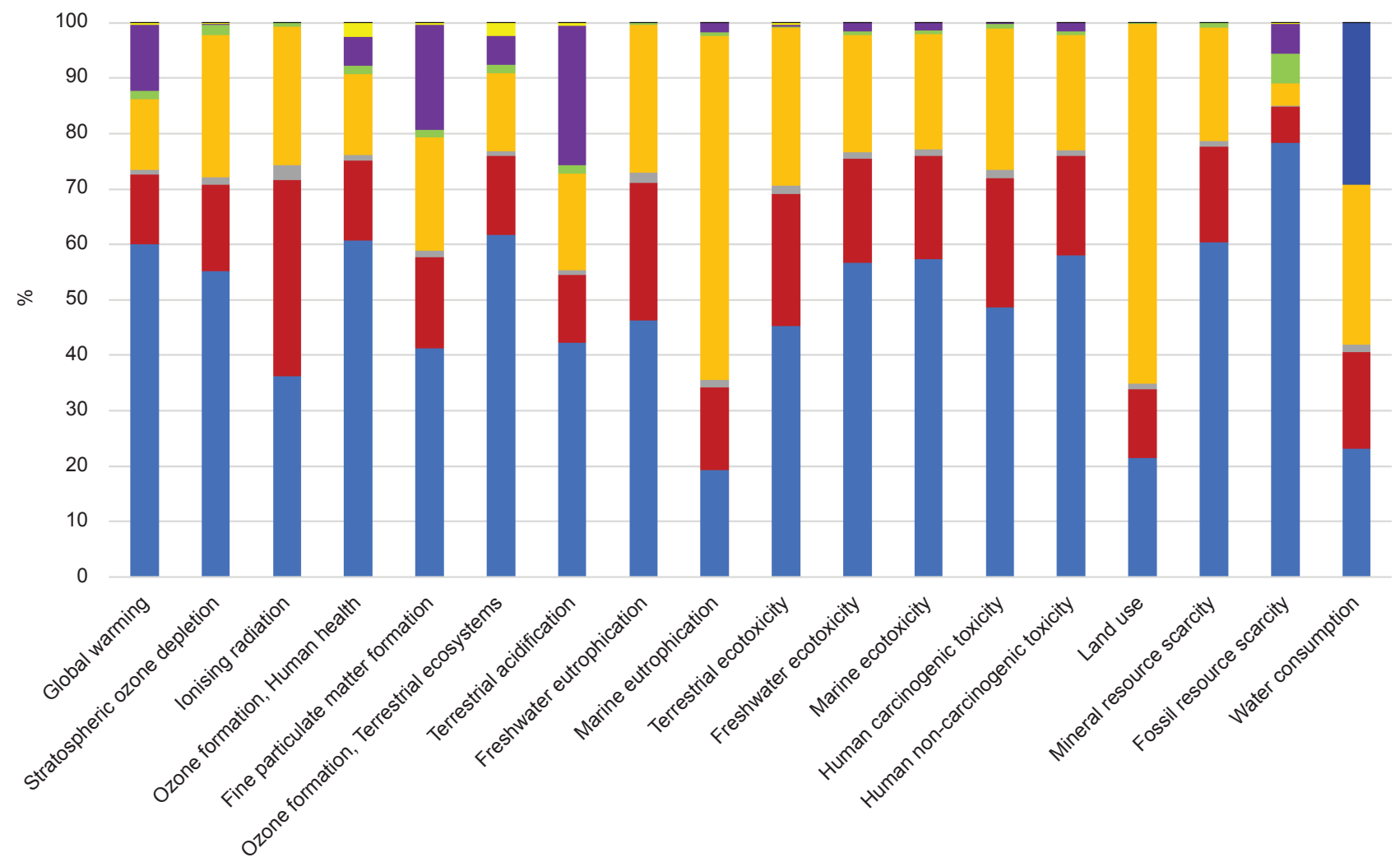

$\square$ Methanol $\square$ Catalyst $\square$ Neutralising agent $\square$ Acids $\square$ Fossil fuels $\square$ Combustion of fossil fuels $\square$ Water $\square$ Transport $\square$ Electricity 


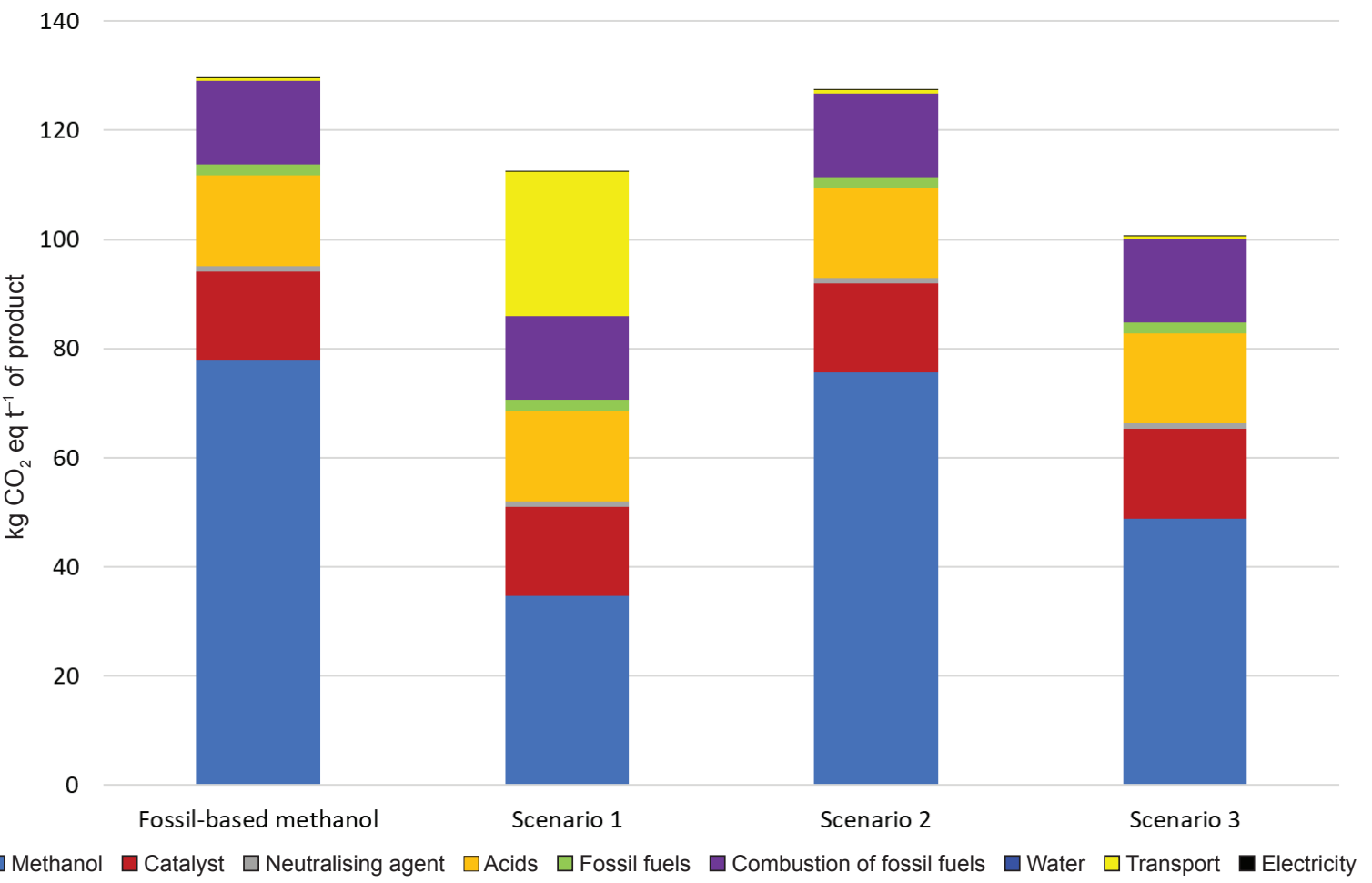

Note: Scenario 1: Replacement of fossil-based methanol with biomethanol produced from biomass in Switzerland; Scenario 2: Replacement of fossil-based methanol with biomethanol produced from biomass in Malaysia; Scenario 3: Replacement of fossil-based methanol with biomethanol produced from biogas in Malaysia.

Figure 3. Global warming for the production of 1 t of palm biodiesel.

25

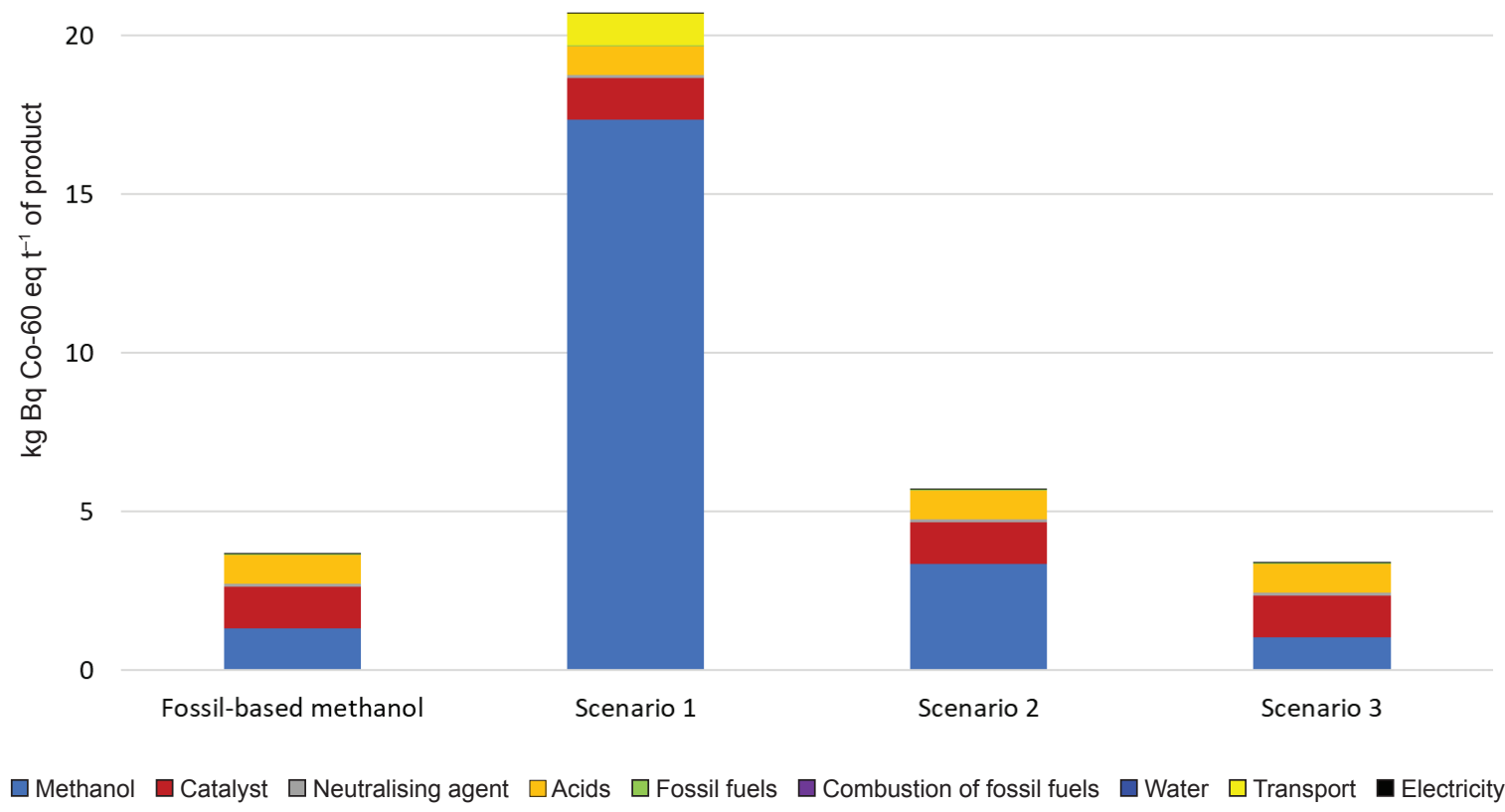

Note: Scenario 1: Replacement of fossil-based methanol with biomethanol produced from biomass in Switzerland; Scenario 2: Replacement of fossil-based methanol with biomethanol produced from biomass in Malaysia; Scenario 3: Replacement of fossil-based methanol with biomethanol produced from biogas in Malaysia.

Figure 4. Ionising radiation for the production of 1 t of palm biodiesel. 


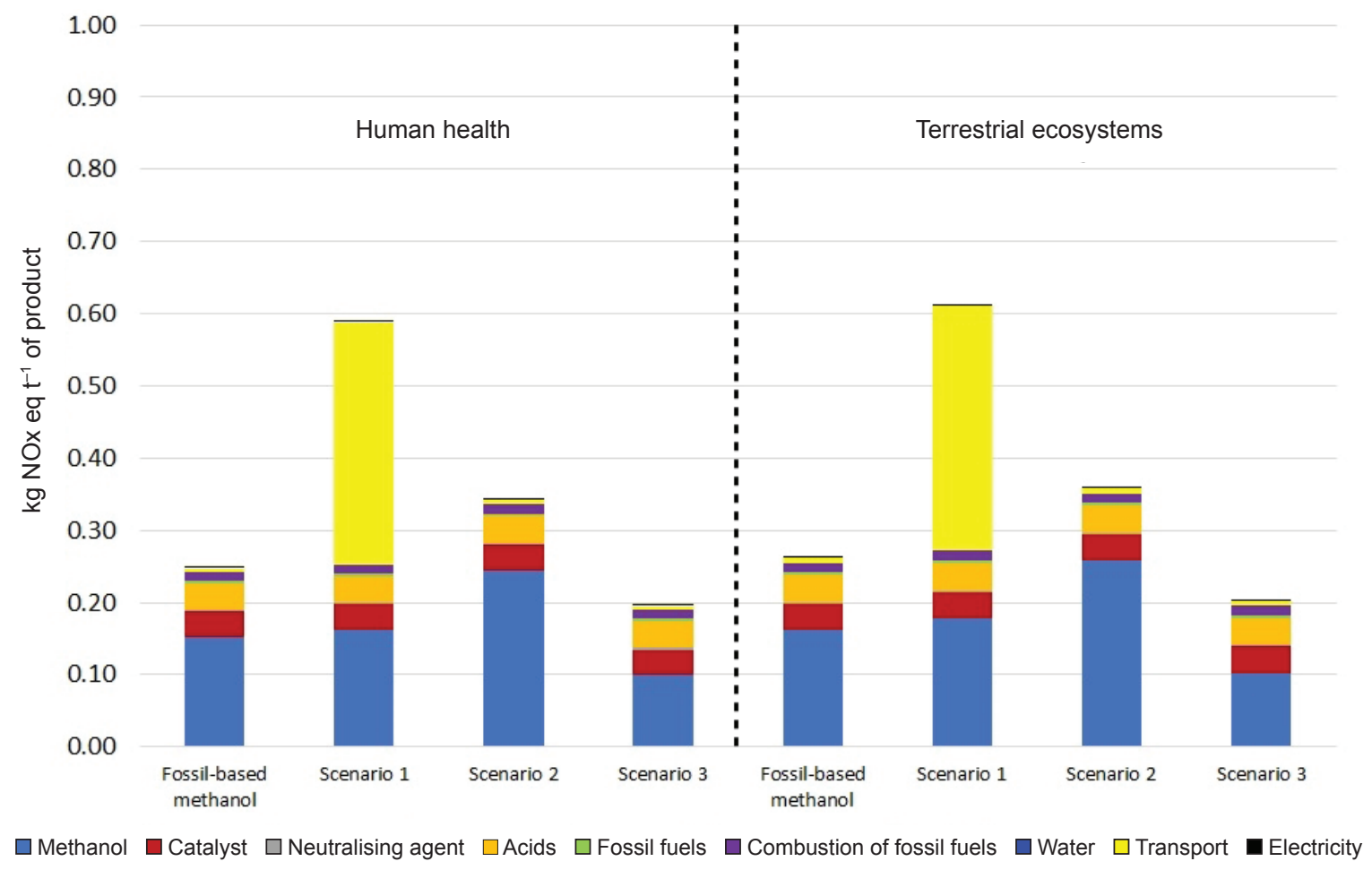

Note: Scenario 1: Replacement of fossil-based methanol with biomethanol produced from biomass in Switzerland; Scenario 2: Replacement of fossil-based methanol with biomethanol produced from biomass in Malaysia; Scenario 3: Replacement of fossil-based methanol with biomethanol produced from biogas in Malaysia.

Figure 5. Ozone formation (human health and terrestrial ecosystems) for the production of 1 t of palm biodiesel.

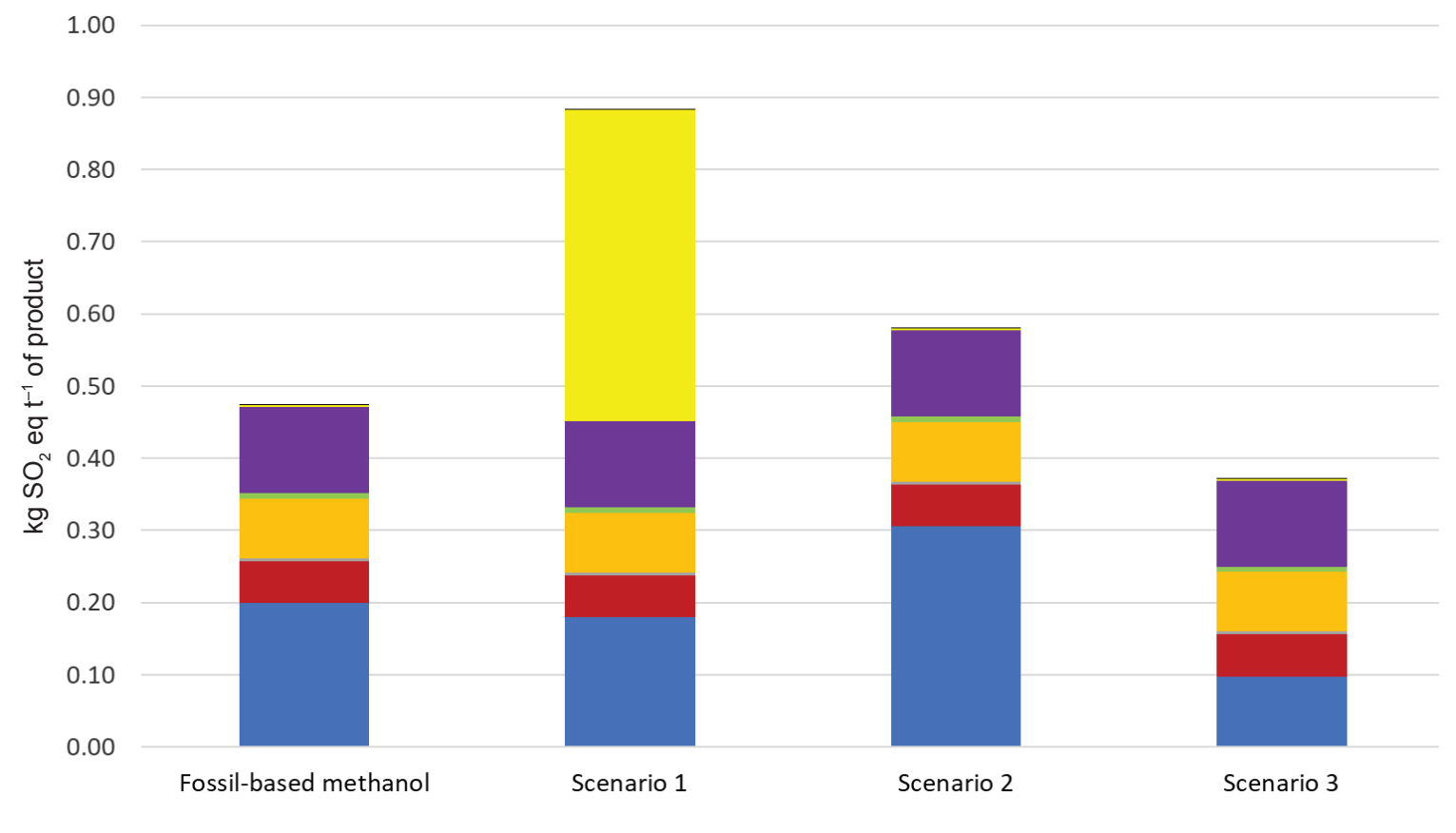

$\square$ Methanol $\square$ Catalyst $\square$ Neutralising agent $\square$ Acids $\square$ Fossil fuels $\square$ Combustion of fossil fuels $\square$ Water $\square$ Transport $\square$ Electricity

Note: Scenario 1: Replacement of fossil-based methanol with biomethanol produced from biomass in Switzerland; Scenario 2: Replacement of fossil-based methanol with biomethanol produced from biomass in Malaysia; Scenario 3: Replacement of fossil-based methanol with biomethanol produced from biogas in Malaysia.

Figure 6. Terrestrial acidification for the production of $1 \mathrm{t}$ of palm biodiesel. 
120

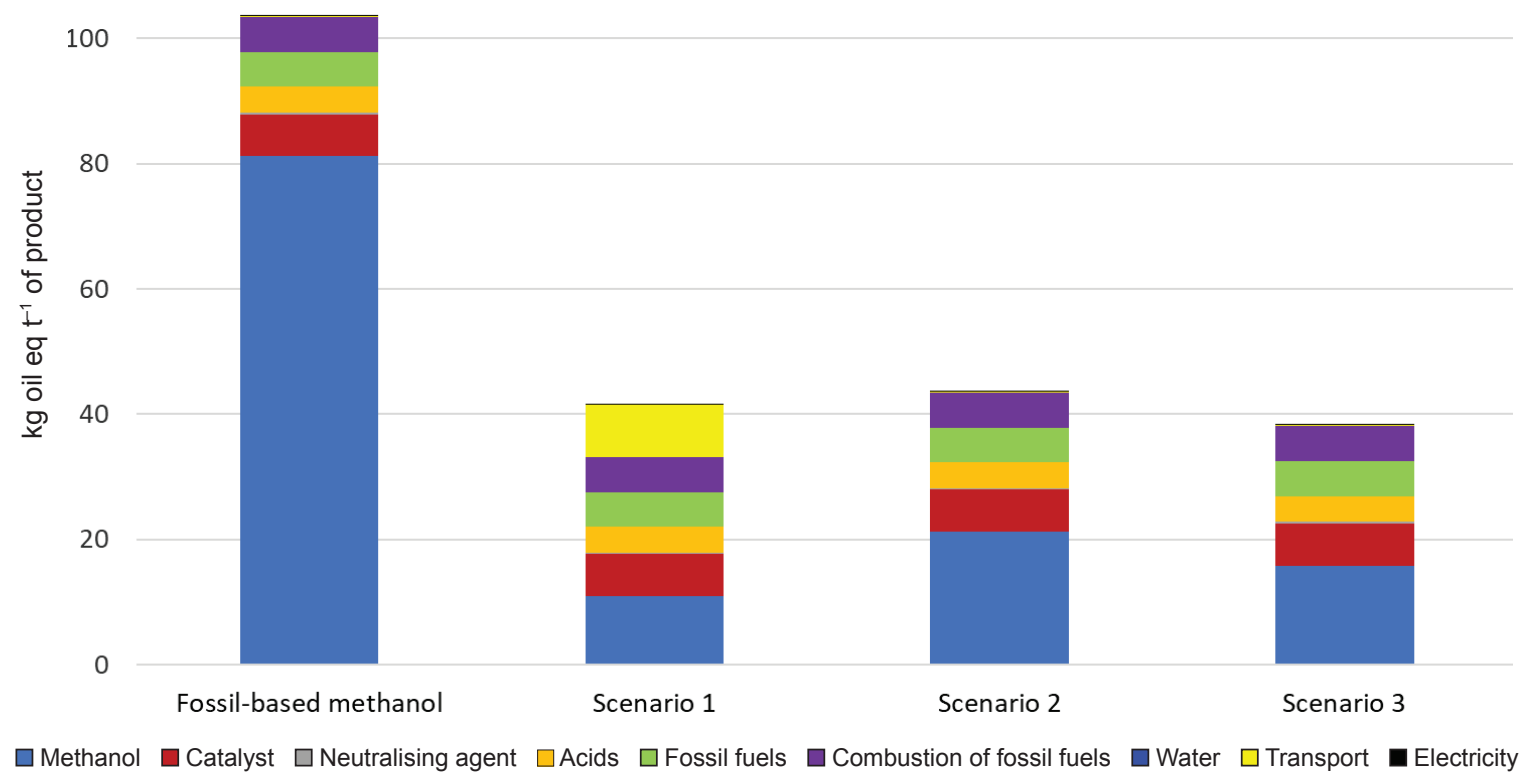

Note: Scenario 1: Replacement of fossil-based methanol with biomethanol produced from biomass in Switzerland; Scenario 2: Replacement of fossil-based methanol with biomethanol produced from biomass in Malaysia; Scenario 3: Replacement of fossil-based methanol with biomethanol produced from biogas in Malaysia.

Figure 7. Fossil resource scarcity for the production of 1 t of palm biodiesel.

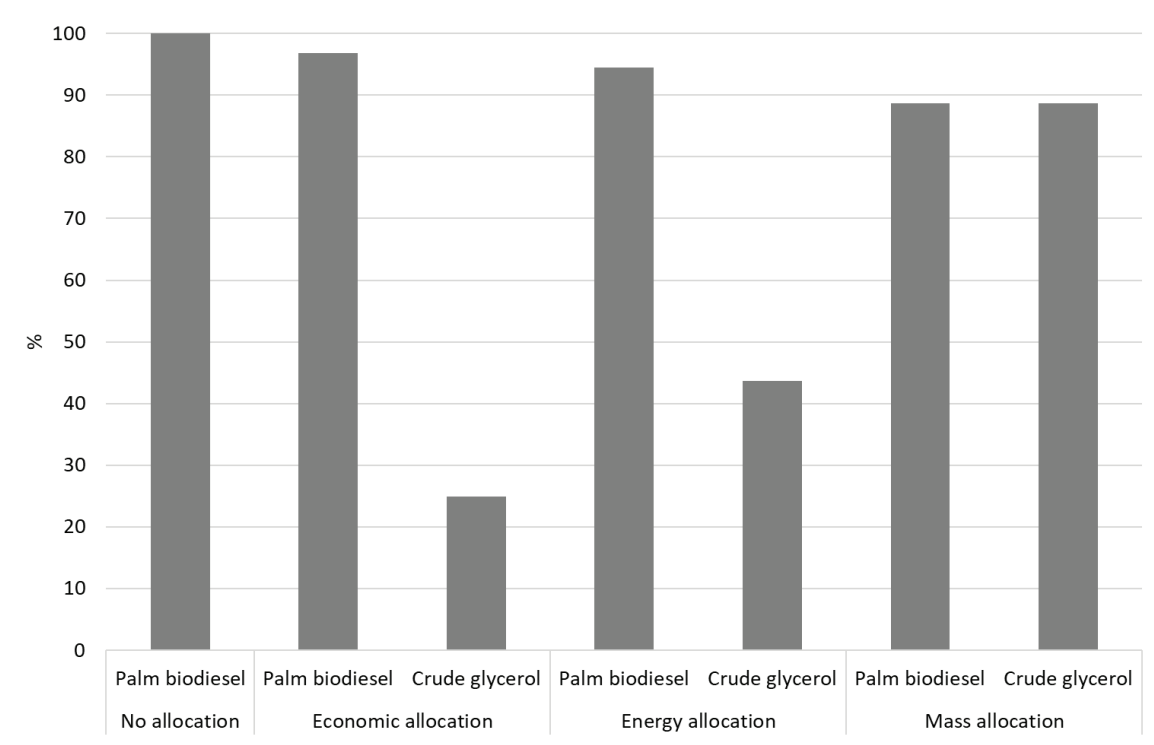

Figure 8. Environmental impacts per tonne of palm biodiesel and per tonne of crude glycerol produced, comparison of different allocation methodologies.

\section{CONCLUSION}

Based on the LCA conducted for commercial palm biodiesel production, methanol, catalyst and acids were the main contributors to the environmental impacts. Replacement of fossilbased methanol with biomethanol was able to lower the overall environmental impact. However, not all the biomethanol sources would have positive contribution to the environmental impact. Biomethanol derived using bio-CNG from POME is the most preferred as it has a positive contribution to the environment, in particular, global warming and fossil scarcity impact categories. As allocation based 
on mass value does not reflect the actual differences of both products (palm biodiesel and crude glycerol) and the amount of crude glycerol used as fuel substitute is insignificant, allocations based on economic value can be more appropriate and relevant as both products are traded commercially in open market at different prices.

\section{ACKNOWLEDGEMENT}

The authors would like to thank the DirectorGeneral of MPOB for permission to publish this artticle. Thanks also due to the palm biodiesel producers for sharing the inventory data.

\section{REFERENCES}

Arvidsson, R; Fransson, K; Froling, M; Svanstrom, M and Molander, S (2012). Energy use indicators in energy and life cycle assessments of biofuels: Review and recommendations. J. Cleaner Prod., 31: 54-61.

Choo, Y M; Halimah, M; Zulkifli, H; Vijaya, S; Puah, C W and Tan, Y A (2011). Determination of GHG contributions by subsystems in the oil palm supply chain using the LCA approach. Int. J. Life Cycle Assess., 16: 669-681.

Department of Standards Malaysia (2014). MS 2008 Malaysian Standard specification for automotive fuels - palm methyl ester (PME) for diesel engines - Requirement and test methods. Department of Standards Malaysia, Ministry of Science, Technology and Innovation, Cyberjaya.

De Souza, S P; Pacca, S; De Avila, M T and Borges, J L B (2010). Greenhouse gas emissions and energy balance of palm oil biofuel. Renewable Energy, 35: 2552-2561.

Harrison, L L N (2018). Status of biodiesel implementation in Malaysia and biodiesel specifications. Paper presented at the $2^{\text {nd }} A P E C$ Workshop on Guidelines toward High Biodiesel Blend Diesel (e.g. B20) Specification in the APEC Region. Hilton Waikiki Beach Hotel, Hawaii, USA. 19 March 2018. https: / / www.egnret.ewg.apec.org / sites / default / files / geektic/web / workshop / 2ndBiodiese $1 \% 20$ workshop / 4_Biodiese $1 \% 20$ Specification-\%20Malaysia.pdf, accessed on 22 August 2019.

Hobson, C and Marquez, C (2018). Renewable Methanol Report. Methanol Institute. https: / / www. methanol.org/wp-content / uploads / 2019/01/ MethanolReport.pdf, accessed on 30 October 2019.
Huijbregts, M A J; Steinmann, Z J N; Elshout, P M F; Stam, G; Verones, F; Veira, M D M; Hollander, A; Zijp, M and Van Zelm, R (2017). ReCiPe 2016 v1.1 A harmonized life cycle assessment method at midpoint and endpoint level. National Institute of Public Health and the Environment, BA Bilthoven, The Netherlands. https: / / www.rivm.nl / documenten/ recipe2016v11, accessed on 23 January 2019.

ISO (2006a). ISO 14040. Environmental management - Life cycle assessment - Principles and framework. The International Organisation for Standardisation, Switzerland.

ISO (2006b). ISO 14044. Environmental management - Life cycle assessment - Requirements and guidelines. The International Organisation for Standardization, Switzerland.

Kittithammavong, V; Arpornpong, N; Charoensaeng, A and Khaodhiar, S (2014). Environmental life cycle assessment of palm oilbased biofuel production from transesterification: greenhouse gas, energy and water balances. Proc. of the 2014 International Conference on Advances in Engineering and Technology. p. 615-621.

Maharjan, S; Wang, W and Teah, H Y (2017). Life cycle assessment of palm-derived biodiesel in Taiwan. Clean Techn. Environ. Policy, 19: 959-969.

Malca, J and Freire, F (2011). Life-cycle studies of biodiesel in Europe: A review addressing the variability of results and modelling issues. Renewable and Sustainable Energy Reviews, 15: 338351.

MarketWatch (2019). Sodium methoxide solution as a biodiesel catalyst market static represent 3.1\% CAGR prospects 2017 to 2018. https:// marketresearch.biz/ report/ sodium-methoxidesolution-as-a-biodiesel-catalyst-market/\# details, accessed on 30 October 2019.

Mohd Nor Azman, A H; Jaramillo, P and Griffin, W M (2011). Life cycle GHG emissions from Malaysian oil palm bioenergy development: The impact on transportation sector's energy security. Energy Policy, 39: 2615-2625.

MPOB (2019). Malaysian Oil Palm Statistics 2018. $38^{\text {th }}$ Edition. MPOB, Bangi.

Norfaradila, J; Norela, S; Salmijah, S and Ismail, B S (2014). Life cycle assessment (LCA) for the production of palm biodiesel: A case study in Malaysia and Thailand. Malays. Appl. Biol., 43(1): 53-63. 
Noorazah, Z; Zulina, A M; Razmah, G and Zainab, I (2017). Environmental assessment on methyl ester production from palm feedstock: A case study. J. Oil Palm Res. Vol. 29(3): 414-423.

PRé Consultants (2018). What's new in SimaPro 8.5. https: / / www.pre-sustainability.com/download/ manuals/SimaPro85WhatIsNew.pdf, accessed on 20 February 2018.

Puah, C W; Choo, Y M and Ma, A N (2010). Life cycle assessment for the production and use of palm biodiesel (part 5). J. Oil Palm Res. Vol. 22: 927-933.

Sampattagul, S; Nutongkaew, P and Kiatsiriroat T (2011). Life cycle assessment of palm oil biodiesel production in Thailand. Int. J. Renewable Energy, 6: $1-14$.

Schneider, L and Finkbeiner, M (2013). Life cycle assessment of EU oilseed crushing and vegetable oil refining. https://www.fediol.eu/ data / 1521124882Full\%20FEDIOL \% 20LCA \% 20 report_05062013_CR\%20statement.pdf, accessed on 24 August 2018.

Silalertruksa, T and Gheewala, S H (2012). Environmental sustainability assessment of palm biodiesel production in Thailand. Energy, 43: 306314.

Siregar, K; Tambunan, A H; Irwanto, A K; Wirawan, S S and Araki, T (2015). A comparison of life cycle assessment on oil palm (Elaeis guineensis Jacq.) and physic nut (Jatropha curcas Linn.) as feedstock for biodiesel production in Indonesia. Energy Procedia, 65: 170-179.

Unnithan, U R (2019). Global development of biodiesel and challenges. Proc. of the PIPOC 2019 International Palm Oil Congress - Chemistry, Processing Technology and Bio-energy Conference. MPOB, Bangi. p. 129-141.

Van Gerpen, J V and Knothe, G (2010). Basic of transesterification reaction. The Biodiesel Handbook. $2^{\text {nd }}$ Edition. AOCS Press, Illinois. p. 31-46.

Yee, K F; Tan, K T; Ahmad, Z A and Lee, K T (2009). Life cycle assessment of palm biodiesel: Revealing facts and benefits for sustainability. Applied Energy, 86: S189-S196.

Yung, C L; Vijaya, S and Sumiani, Y (2020). Life cycle assessment for palm oil refining and fractionation. $J$. Oil Palm Res. Vol. 32(2): 341-354. 